Калядка Святлана

Мiнск

\title{
Эмацыянальны канцэпт: тэорыя і практыка ў паэзіі Максіма Танка
}

У традыцыйным літаратуразнаўстве даследчыкі вылучалі праблему «паэта і паэзіі» як датычную ўсіх творцаў. Рэдкі аўтар не звяртаўся да рэфлексійнай ацэнкі ўласнай творчасці $\ddot{y}$ вершах, рэдкі аўтар не агучваў пытанне будучыні яго творчасці ў яго ж творах. Тое ж мы можам сказаць і пра паэзію Максіма Танка, у якой экзістэнцыя Максіма Танка як паэта і чалавека ўзнаўляецца па вершах. Яны як прыступкі па лесвіцы лёсу, як дарожныя слупы, якія абазначаюць траекторыю руху асобы у будучыню, у вечнасць. Максіму Танку было важна не саступіць з гэтай дарогі, выпадкова не збочыць і не зайсці на іншыя, чужыя. Таму у яго творчасці знойдзем шмат вершаў, у якіх ён узнімае экзістэнцыяльную праблему быцця паэта. Многія вобразы ў спосабах адлюстравання азначанай праблемы набылі характар канцэптаў.

Звяртаючыся да кагнітыўнай лінгвістыкі і непасрэдна да вызначэння канцэпта, варта адзначыць, што да гэтага часу няма адзінага i фундаментальнага тэарэтычнага грунту ў адносінах да названага паняцця. Кагніцыя - як спосаб засваення ці адлюстравання рэальнасці, мае як універсальны, так і індывідуальны характар, асабліва у дачыненні да Чалавека творчага. Мы ў даследаванні будзем абапірацца на вызначэнне канцэпта як ментальнай асаџылтыўнай сутнасці, ментальнай рэпрэзентачьі аб'ектаў, вобразай рэальнага свету, закадзіраваньх нашай свядомасию ${ }^{1}$. Прамое значэнне слова, закладзенае

1 Л. М. Васильев, О понятиях и терминах когнитивной лингвистики / Концептыл культуры в языке и тексте: теория и анализ, под ред. А. Киклевича и А. Камаловой, Olsztyn 2010, с. 13. 
у яго семантыцы, для творцы - гэта ўсяго іканічны знак, які мае семіятычную функцыю. Апісальныя мастацкія вобразы адлюстроўваюць эмпірычны бок канцэпта $\ddot{y}$ адрозненне ад яго другога лагічнага (рацыянальнага) боку, які знаходзіць адлюстраванне ў абстрактных, а іншым разам і размытых значэннях слоў. Калі звярнуцца да гісторы беларускай літаратуры XX стагоддзя, то можам убачыць, што у шматлікіх аўтараў былі актуалізаванымі канцэпты выъбар, зямля, радзіма і інш., якія набывалі ўніверсальны характар і прыпадабнялі розныя светаўспрыманні ў спосабе адлюстравання свету праз ключавыя паняцці і катэгоры культуры і літаратуры. Нас жа ў большай ступені цікавяць індывідуальна-аўтарскія спосабы адлюстравання двуадзінства «чалавек - свет». Індывідуальна-аўтарская карціна свету, выражаная праз аксіялагічнае, культурнае, эстэтычнае і г.д. напаўненне знакай мастацкага тэксту, набывае статус канцэптасферы, калі спосабы вербалізацыі ў мастацкім творы набываюць агульначалавечае значэнне ці ўспрымаюцца агульназразумелымі для «Другога». Іншымі словамі - аўтар павінен стаць Асобай, якая адкрывае Свет для ўсіх нас праз аказіянальныя аўтарскія метафары пазнання рэчаіснасці, яе апісання і ўвасаблення ў мастацкіх вобразах, а аўтарскія аказіяналізмы набываюць ролю канструктаў, якія рэканструіруюць нашу свядомасць. Карыстаючыся мовай лінгвістаў, новае бачанне знаёмага ўсім свету, выражанае $\breve{y}$ канцэптах, павінна набываць адно значэнне, іншыя сэнсы працуюць на ўзмацненне гэтага значэння, толькі тады можна гаварыць пра наяўнасць агульнай мовы паміж аўтарам і чытачом. У літаратуразнаўстве ў розныя перыяды гістарычнага развіцця грамадства пад «значэннем» мастацкага твора разумеліся розныя лёгка уизнайляльныя анталагічныя стандарты: роля будаўніка сацыялістычнага грамадства, духойнага асветніка, катарсіснага ачышчэння душы і г. д. На сённяшні дзень «значэнне» твора згубіла/пазбавілася/не набыло новай парадыгмы, мы можам падыходзіць суб'ектыўна да выбару і ацэнкі твора па патрэбе душы і розуму, настрою і імпульсіўных памкненняў і г. д., але вызначыць адзінае «значэнне» для твора сучаснай літаратуры немагчыма, а можа i не трэба. Калі гаварыць абагулена, у спосабах пазнання свету прэвалююць не асацыятыўныя, а дысацыятыўныя працэсы. Сучаснаму маладому аўтару цікавей раскласці рэаліі на складнікі (як таму дашкольніку зразумець, з чаго складаецца цацка), чым шукаць новага «абасалюту». Магчыма, у такім дзіцячым памкненні да асноў, у пошуках прататыпу ўсяго існага і бачацца тэндэнцыі зараджэння новай культурнай парадыгмы. 
У мастацкім творы аказіянальныя канцэпты часта не выражаны словам, яны лунаюць над словамі, іх адчуваеш, як пах паветра пасля дажджу, аднак знайсці патрэбныя словы для іх апісання вельмі цяжка. У віртуозных мастакоў, як і у віртуозных музыкантаў, цяжка рэканструяваць канцэпты «гульні»- i слова, і гук увесь час выпадаюць з устаялых мадэляў і стандартаў іх успрымання. Часта твор нагадвае сузіранне аўтарам самога сябе праз мастацкае слова, у вобразах і фантасмагорыях, далёкіх ад яго асабістага жыцця. Змясиічь усюды самога сябе (выраз філосафа В. В. Калінічэнкі), адразу апынуцца ва ўсіх часта непарайнальных і несупастаўляльных вобразах можа толькі Чалавек творчы. Зыходзячы з гэтага, недастаткова кантэкстуальнага, кампанентнага ці трансфармацыйнага аналізу, каб разглядзець, што ёсць яшчэ у аўтара за агульназразумелымі значэннямі слоў, неабходна звяртацца да міждысцыплінарнага дыскурсу, да гісторыі слова ў філасофіi, рэлігіi, сацыялогіi, культуралогіi і іншых дысцыплінах, да спецыфікі нацыянальных стэрэатыпаў і ўяўленняў. Быццам бы прапісныя ісціны, аднак аўтарская свядомасць таленавітага мастака заўсёды адкрытая кніга, поўная асаблівасцей канцэптуалізацыі і катэгарызацыі з'яў рэчаіснасці і пазарэчаіснага свету. А калі на думку накладваецца эмоцыя, то канцэпт набывае і новую канататыўную афарбоўку, і новае падсвечванне.

У сваім даследаванні мы звязваем эмацыянальны канцэпт з эмацыянальным інтэлектам. Эмацыянальны інтэлект пісьменніка звязаны 3 магчымасцямі, уменнямі асэнсаваць эмоцы $\ddot{y}$ сабе і перанесці ix у вобразы паэзіі. Ці інакш, у эмацыянальным інтэлекце паэта зафіксавана своеасаблівая манера адчуваць, асэнсойваць, думаць праз эмацыянальнае адлюстраванне аб'ектаў, прадметаў, з'яў і г. д. рэчаіснасці у вобразах паэзіі. Эмацыянальны інтэлект здольны нараджаць эмацыянальныя вобразы: адны з іх маюць традыцыйную прыроду і суадносяцца з псіха-фізіялагічнымі станамі чалавека (радасць, боль, засмучэнне і г. д.), іншыя канцэптуалізуюцца, адсылаючы чытача да архетыпаў (канцэпты мачі, радзіма, дарога і інш.), а некаторыя маюць зварот да сферы пачуццяў, перажыванняў і эмоцый чытача (канцэпты вайна, песня, вяселле і інш.). Канцэпты вайна, песня, вяселле семантычна пашыраюцца за кошт гістарычнай шматслойнасці: для славяніна гэта не проста словы, якія фіксуюць пэўныя з'явы нашага жыцця, а глыбінныя крыніцы эмоцый. «Вайна» асацыюецца са смерцю, прыніжэннем, прыгнётам, знішчэннем мільёнаў (гэта інфармацыя ў сучасных пакаленняў ужо на ўзройні генетычнай памяці пра Вялікую Айчынную вайну), а значыць мае сувязь 3 негатыўнымі эмоцыямі, 
«вяселле» - са святам, новым этапам жыцця, злучэннем двух лёсай у адзін і г. д., а значыць са станойчымі эмоцыямі. I за ўсімі гэтымі канцэптамі зварот да агульнай гістарычнай памяці, да свядомага і неўсвядомленага, лагічнага і эмацыянальнага. Значыць, эмацыянальны канцэпт - гэта ментальная рэпрэзентацыя вобразаў рэчаіснасці, звязаная са здольнасцю эмацыянальнага інтэлекта трансліраваць праз вобразы пэўныя эмоцыі і замацоўваць за імі ўстойлівыя значэнні. Такім чынам, для вызначэння эмацыянальнага канцэпта ў паэтычным творы неабходна задзейнічаць метадалагічныя падыходы літаратуразнаўства, кагнітыўнай лінгвістыкі і кагнітыўнай псіхалогіi. Эмацыянальны канцэпт - утварэнне гэтых трох дысцыплін. Ён апелюе да эмацыянальнай сферы чалавека, якая «замацоўваецца» у вобразах паэзіі праз мастацкія коды, што ўзнайляюцца ў свядомасці чытача як агульнавядомыя. Так, канцэпт песня апрыёры мае эмацыянальны характар, таму што сама лексема песня раскадзіруецца ў нашай свядомасці як разнастайнасць сумных і вясёлых, пахавальных і вясельных, народных і эстрадных і г.д. яе відаў, якія звязаны з пэўнымі эмацыянальнымі сітуацыямі ӱ жыцці асобы.

Якую дынаміку набываюць эмоцыі, закадзіраваныя ў канцэпце $n e c$ ня, што праходзіць праз усю творчасць Максіма Танка? Ва ўступным артыкуле да Збору творай Васіль Зуёнак заўважыў: Паэзія Максіма Танка ўся ад зямлі, ад лёсу людскога. Адны ўжо назвы яго кніг гучаць, як песня жыция ${ }^{2}$ У выказванні Васіля Зуёнка не прагматычнае прадумванне, а эмацыянальны водгук, ён імкнецца знайсці менавіта эмацыянальны адпаведнік у ацэнцы творчасці паэта. У сучасных беларускіх часопісах часта праводзяць апытанне, якім мы бачым ці ўяуляем для сябе таго ці іншага пісьменніка, і нам трэба даць ацэнку у некальніх найменнях. Як паказвае практыка, часцей за ўсё гучаць менавіта эмацыянальныя ацэнкі, кшталту экспрэсіўны, «жывы», яркі, самабытны і г.д. Таму і песня жыция у назвах кніг не проста метафара, гэта акцэнтаванне на спосабе існавання Максіма Танка ӱ творчасці. Цэнтрызм канцэпта песня у у творчасці Танка невыпадковы: у ім закадзіраваны трансцэндэнтны і іманентны планы быцця паэта. Праз песню паэт вядзе дыялог са светам, з Богам і сабой. Хто ёсць Бог для Танка? Гэта не хрысціянскі Бог і не яго сын Хрыстос, да Бога паэт звярнуўся толькі на апошнім этапе творчасці. Падаецца, што сама паэ-

2 В. Зуёнак, Пад нарачанскім знакам, (у:) Максім Танк, Збор твораў: у 13 m., Паэзія, Мінск 2006, т. 1, с. 14. 
зія набыла для яго сакральны сэнс быцця, у ёй паэт маліӱся і каяўся, грашыў і прасій прабачэння. Яна для яго Бог.

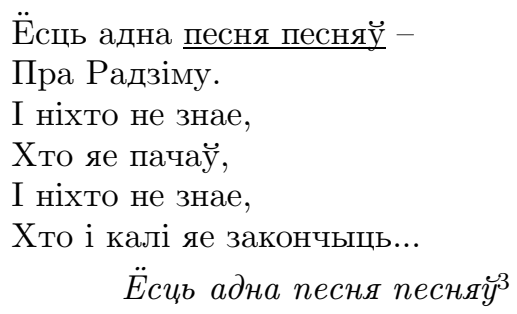

Нездарма Максім Танк звяртаецца да правобраза «песні песняў» Саламонавай як да вытоку існага ў творчасці, як пратэксту, можна нават сказаць, іканічнаму вобразу і г. д. Пасля радка Пра Радзіму - кропка, як знак адной ісціны. Радзіма для Максіма Танка - шматузроўневы вобраз, у якім перакрыжойваюцца плоскасці рэальнага і фантасмагарычнага, наяўнага і незямнога, аб'ектнага і нявызначанага абстрактнага, аднаспектральнага i мазаічнага і г. д. Верш Максіма Танка мае рытарычную скіраванасць - акрэсліць канцэптуалізацыю ўласнай творчасці - ствараць «песню пра Радзіму», а гэтым і вызначыць мадальнасць творчага метаду. У перадваенны час падзеі ў лірыцы разгортваюцца на пераломе жалеза $i$ песні... Песня - як славесна выражаная кропка быцця, у ёй, быццам у кроплі расы, адлюстроўваецца свет і чалавек у дадзеных часе і прасторы. I чым болей ты пішаш, тым больш цябе самога застаецца ў гэтых кропках у гісторыі чалавецтва. У 1930 годзе быў напісаны верш «***Колькі часу шукаў я...», які і сёння гучыць маніфестам творчасці Максіма Танка:

Цяпер, песня, я буду

Ісці аж да сонца

Тваім сцяганосцам.

Пазіцыянаваная праграма паэта Максіма Танка $\breve{y}$ нечым супярэчыць антрапацэнтрычнай парадыгме літаратуры сацрэалізма таго часу, але ж і радзіма, і песня паэта на службе чалавеку. На пачатку творчасці, у давераснёўскі перыяд, Максім Танк у большай ступені рытар, трыбун, чым Чалавек «чувствующий». А трыбунная паэзія патрабавала эмацыянальнага напалу, нават эмацыянальнай злосці і нахабства. Таму у вершах Максіма Танка сустрэнем эмацыянальнае выражэнне

3 3. Максім Танк, Збор твораў: у 13 т., т. 1-6. Паэзія, Мінск 2006-2008, т. 6, с. 200. Далей пры спасылцы на гэта выданне ў дужках падаюцца том і старонка. 
свабодалюбівых пазіцый асобы праз адчаканеныя рытмы «маякойскіх» радкой: ...мая песня / Навальнічай весняй крышыць крыгі», «яна палае / Пад дзяругай незгасальньм сончам», «...але ім (катам) не ўдасца маю песню / Заняволічь, закавачь у путы (***ККожны дзень шукаюць маю песню). У гэтым і іншых вершах давераснёўскага перыяду адлюстравана нацыянальна-культурная спецыфіка абазначэння, апісання і выражэння эмоцый, звязаных з неабходнасцю шыфраваць тэксты, займацца канспірацыяй і перазахойваннем тэкстаў. Сітуацыя знаходжання пад кантролем польскіх улад актуалізавала пэўны набор мастацкіх сродкаў, сярод якіх эмоцыі адчаю і гневу станавіліся выразнікамі эматыўнай прасторы прыгнечанай асобы.

Чалавек прыгнечаны у паэзіі Максіма Танка не гаворыць на мове прыгнечанага, ён супраціўляецца ўладзе, абставінам, часу. У вершы «Песня» (1931) паэт заклікае:

Змагацца за волю вядзі ўсіх бяздольных,

Мільёны прыгнечаных і беспрацоўных,

Мільёны рабочых, сялян, паднявольных, -

Пара падымацца, пара!

Эмацыянальная ӱзрушанасць аўтара ў падобных тэкстах суправаджаецца клічнікам: Вугля кінь у горны!! / I парыу сіль, бунтарны $i$ свежы, / $\check{У}$ нашых жылах, з песняй звонячь, хай б’ециа $(1,54)$. Калі пагартаць першыя кнігі аўтара, то заўважым наяўнасць мноства клічнікавых канструкцый, якія працуюць на фарміраванне вобраза бясстрашнага змагара, актывіста-лідара, які вядзе за сабой масы. У перадваенны час у творчасці Максіма Танка прэвалюе тэматычны вектар вызвалення цела, душы і свядомасці з-пад улады і кантролю паноў. Маніфестацыя эмоцый набывае гісторыка-культурную прывязку, перадае нацыянальную трагедыю залежнага становішча народа. Як адзначаў сам аўтар, Вершам сёння - кожны камень, / Кожны выступ, залом иагляны, / Кожны дзень, Кастрычнік, Травень, / Кожны крок усхваляваньл.

Эмоцыя - гэта не разавы кампанент, эмоцыя у нашым даследаванні атаясамліваецца з эмацыянальнай прасторай паэтычнага твоpa i творчасці аўтара $\ddot{y}$ пэўныя перыяды, разбіўка на якія вызначана гісторыкамі літаратуры. У эмацыянальнай прасторы не толькі адлюстройваецца, але і прадвызначаецца, не толькі фарміруецца, але і прадчуваецца, не столькі тыпізуецца, колькі індывідуалізуецца тып мастацкага мыслення і свядомасці аўтара. Вызначэнне «эмацыянальная прастора мастацкага тэксту»- паняцце рода-віда- 
вое, якое патрэбна ўключыць у літаратуразнайчую эматыялогію. Эмаиыянальная прастора - гэта і нацыянальныя аспекты самараскрыцця аўтара, і эматыўныя сэнсы слова, выказвання, вобраза, і індывідуальная рэакцыя на апісваемыя падзеі, і выражэнне імпульсіӱных часо-

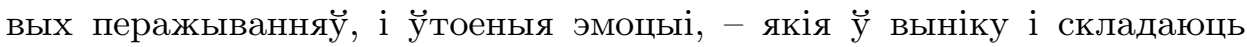
эматыўную характарыстыку асобы аўтара і яго эмацыянальнага інтэлекту, што, у сваю чаргу, прадвызначае стварэнне пэўных канцэптаў у паэтычным творы. Чалавек стрыманы па тэмпераменце без ярка выражанага эмацыянальнага інтэлекту не зможа нарадзіць эмацыянальны твор - усё ройна шмат чаго $\ddot{y}$ ім будзе штучнага і ненатуральнага. Але варта помніць, што знешняе праяўленне эмоцый і эмацыянальны стан душы могуць не супадаць. Эмоцыя таксама можа мець кансерватыўную прыроду, як і мысленне кансерватыўнага чалавека і пісьменніка, а можа мець і прагрэсіўную. Яна можа рухацца наперадзе твора, падцягваючы пад сябе ўспрыманне ўсяго тэксту. Напрыклад, у вершы «Тры песні» (1936):

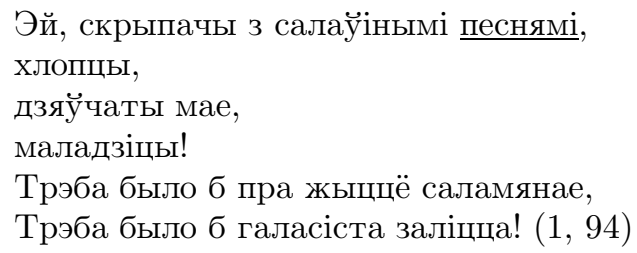

Зачын твора ўтрымлівае ў сабе цэлы кангламерат супярэчлівых, нават супрацьлеглых эмоцый, якія прадвызначаюць танальнасць усяго твора. «Салаўіная песня» адлюстройвае ў падтэксце рэальныя падзеі барацьбы, выкліканай несвабодай народа. Прафанацыя яе першаснасці для асобы адлюстройваецца ў выглядзе апявання прыроднай прыгажосці. Калі звярнуцца да народнай творчасці, то вобраз салайінай песні (дарэчы, вельмі папулярны ў творчасці Танка) убірае у с сябе не толькі атаясамліванне з непайторнасцю і ўнікальнасцю прыроднага свету, з маладосцю, радасцю, палётам мары і ціхім сумам, але і з далучанасцю прыроднага свету да народнага гора і няшчасцяў, калі салавей становіцца вестуном бяды. Гэты матыў выкарыстойвае і Максім Танк, яго салайіная песня выступае казкай иі былінаю / аб чорнылм крылвавылм загоне. Палітычны рэжым несвабоды нараджае своеасаблівы эмацыянальны рэжым: эмоцыі рухаюцца па пэўнай траекторыі, знаходзячыся у межах палярнай дыхатаміі несвабода-вызваленне.

Эмоцыя можа ісці і $\breve{y}$ разрэз з выказанай думкай у першай частцы твора, як гэта адбываецца ў вершы «***ЖКаць ідзе батрачка ра- 
на...»: вобраз хусткі злучае два бакі эмоцый - Вочь хусткай вылиіpaе / Хусткай, што купіў Рьгор і На расстанні ёй пакінуў / Хустку з песняю сваёи. Бінарызм эмацыянальнага стану - з аднаго боку, душэўны боль і жаль, з другога - вера і надзея (Гаварылла гэта песня, / Што парвуича кайдань) скіраваны на адлюстраванне гістарычнага злому, калі, у адпаведнасці з марксісцкай праграмай, вярхі не могуць правіць па-новаму, а нізы не хочуць жыць па-старому. У вершах давераснёўскага перыяду адчуваем вострую эмацыянальную рэакцыю Максіма Танка на грамадскі ўклад таго часу. А таму эмацыянальная прастора яго твораў прасякаецца болем тысяч прыгнечаных, крыкам тысяч згубіўшых сваіх родных і блізкіх, горам матак, не дакачаўшыхся сваіх сыноў з рэвалюцыйных барыкад і выступленняў. Канцэпт песня нібы расслойваецца на некалькі пластой, што нябачнымі шляхамі пераходзяць адзін у аднаго. Даваенная песня Максіма Танка крывавіць ранамі вызваленцаў радзімы ад панскага ярма, яна - чырвонага колеру. Гэта песня прадугадвае рэканфігурацыю эмацыянальнага вопыту у ваенны час, а затым - і $\ddot{y}$ пасляваенны.

У 30-ыя гады канцэпт песня звязаны з аўтарскай ідэяй вызвалення Заходняй Беларусі ад панскай Польшчы. Зварот у мінулае прыводзіць да аднаго і таго ж тыпу эмацыянальна негатыўнага ўспрымання рэчаіснасці праз звон кайданоў: $A$ іншьх сам не знаю, дзе шукащь. / Аклікну песняй - $і$ ў адказ заўсёды / Прыглушаны звон кайданоў чуващь... $(1,93)$. Эмацыянальны фон ідэйнага выражэння у творы падпарадкуецца дэтэрмінізму атрымання свабоды: Беларусь, хутка будзеш свабоднаю, / Заквітнееш красой маладой. / Так хачеў бъ иябе, мая родная, / Прьвітаць новай песняй сваёй. (1, 61). У вобразе «новай песні» закладзены пакуль што прыхаваныя эмоцыі радасці, шчасця, невядомага пакуль што пачуцця свабоды.

Калі ў перадваенны перыяд творчасці дамінавалі эмоцыі жалю, шкадавання, веры і надзеі, выкліканыя жаданнем вызвалення з путаў няволі, то ӱ ваенны перыяд уладарыць эмоцыя гневу, што сыходзіць з імкнення захаваць доўгачаканую свабоду ад новых прыгнятальнікай - фашыстаў. Бінарная апазіцыя «знайсці-захаваць» вызначае і матывацыю нараджэння песні:

Гэта песня прайшла праз гады і муры, Павуцінне парваўшы калючых дратоў.

Гэта песня гарэла ўначы і гарыць -

I таму на цымбалы кладу яе зноў.

$$
\text { Гэта песня }(2,6)
$$


Песня надзяляецца антрапаморфнымі прыкметамі, яна як жывая істота ўдзельнічае ў змяненні свету і чалавека. Песня Максіма Танка чуйна адгукаецца на малейшыя пераўтварэнні ў грамадстве, свядомасці і душы чалавека. А таму яна жыве іх эмоцыямі. У творчасці Максіма Танка адбываецца эвалюцыя эмоцый як рытарычных канструктаў, якія адлюстройваюць змену пэўных сацыяльных, палітычных, грамадскіх ідэалогій. У 1941 годзе аўтар піша верш «Не шкадуйце, хлопцы, пораху...», у якім вобраз песні нясе на сабе функцыі абуджальніка патрыятычнай свядомасці народа: Чующь гады ў кожным шораху, / Што ўжо блізічиа расплата, / Чуюиь з страхам песню ворагі: / Не шкадуйче, хлопчьl, nораху / На катаў! $(2,15)$. Гучныя акорды песні-помсты падхоплівае прырода, ва ўнісон з чалавекам услаўляючы пераможцаў і праклінаючы забойцаў: I дзень $i$ ноч гудуць на Беларусі / Пра нашу славу вольньяя вятрьг; / I дзень $і$ ноч пяюиь на Беларусі / Пра партызанаў нівы $і$ бары (т. 2, 24). Ваенная лірыка прасякнута эмоцыямі-заклікамі, эмоцыямі-прысягамі, менавіта у гэты няпросты для краіны час эмацыянальны пачатак прэваляваў у паэзіі ў спосабах перадачы ўнутранага стану чалавека на вайне. Пазней, пасля вайны, у ваеннай прозе і паэзіі аўтары будуць шукаць гнасеалагічныя, аксіялагічныя, этычныя аснаванні чалавечых перажыванняў, а ў перыяд ваенных дзеянняў байцу патрэбна была эмацыянальная падтрымка, якую ён часта знаходзіў у песні. Нездарма падчас Вялікай Айчыннай вайны было напісана столькі песняў-гімнаў, песняў-прызнанняў, якія прыдавалі веры, напаўнялі сэрца цеплынёю, якой не хапала ў акопах і траншэях. Вызваленая родная зямля давала крылы паэзіі, натхняла на новыя творчыя пошукі:

\author{
Я толькі вуснамі прыпаў \\ Да чорных скіб тваіх, - увесь я \\ Раскалыханым звонам стаў, \\ I крылы выраслі ў песні. \\ Бальшак бярозавы пралёг $(2,29)$
}

У вершах Максіма Танка не толькі прырода персаніфікуецца, але і сам чалавек апрадмечваецца (увесь я / Раскальханым звонам стаў). Акрыленая песня здольна набыць жыццесцвярджальную сутнасць, весці чалавека за сабой да заваявання новых вышынь, пераадолення ўсіх перашкод.

Калі у вершах ваеннага перыяду прысутнічае пэўная адналінейнасць у выражэнні эмоцый, то ў пасляваенны перыяд у паэзіі пачынае раскрывацца амбівалентнасць эмацыянальных станаў, выкліканых 
рознымі падзеямі, якая найбольш выявілася у 1990-ыя гады. Калі гаварыць банальна, Максім Танк не імкнуўся прытрымлівацца так званай эмацыянальнай нормы, устаноўленай апалагетыкай сацрэалізму. Яго песня шукала новых сэнсаў. Але пры гэтым Танк не мог не быць выразнікам «сканструяваных» традыцыяй, культурай эмоцый, пачуццяў і перажыванняй - ён быў паэтам свайго часу:

Я на паэзіі магутных крылах

Не раз да зор далёкіх залятаў,

Але мяне з непераможнай сілай

Зямля цягнула да штодзённых спрай.

Табе $(3,15)$

«Зямное» паходжанне ліры паэта $\ddot{y}$ многім адпавядала лініі сацрэалізму - адлюстройваць чалавека працы, яго працоўныя подзвігі (Я бый знаёмь з німфамі, з багамі, / Разгледзеў марнасџь $і$ бяссілле іх, / Таму людзей за плугам, за станкамі / Я праслаўляў y песняx y сваіх $(3,15)$. Канцэпт песня ўпісваўся у тыя і зацверджаныя партыяй стэрэатыпы і каноны сапраўднага пісьма. Пафасная эмоцыя напаўняла гімны нястомнай руплівасці селяніна. У пасляваенны перыяд краіне патрэбны былі перадавікі, рацыяналізатары, стаханаўцы і заваёӱнікі неабжытых прастораў вялікага Савецкага Саюза. I да іх Максім Танк скіроўваў сваю песню у 50-60-ыя гады XX стагоддзя. Эмоцыя была звернута да аб'ектывацыі ўнутраных імпульсай асобы, да ўніверсалізацыі памкненняў быць лепшым у працы. Эмоцыя ўдзельнічала ў стварэнні канкурэнцыі і сацыялістычных спаборніцтваў, у праслаўленні рабочага чалавека сваёй радзімы:

\begin{abstract}
А словы складаць у песні, Легенды, балады, сказы Я ӱзяуся таму, што гэта Закінутай праца была, I перад радзімай хацеў я Выканаць свой абавязак, Каб слава майго народа Заўсёды і ў песні жыла.
\end{abstract}

Пра сябе $(3,27)$

Стварэнне песні, як піша Максім Танк, гэта праца, прычым няпростая праца. У дзённіках сустрэнем наступнае меркаванне Танка 
пра паэта і паэзію: Пісьменнік не можа быиь староннім назіральнікам, абыякавым чалавекам. Ён павінен $і$ абавязань кожную праблему прапусціиь праз сябе, асвятліџь сваім розумам, насыціџь крывеёю свайго сэрча, адным словам, «ачалавечьцьь». «Ачалавечаная» песня паэта жыве ўсімі чалавечымі эмоцыямі, асабліва поўна і шматбакова гэта праявілася ў 1970-90-ыя гады. Пры ўсім шматабліччы падыходаў і метадалогій даследавання эмоцый зразумела, што нашы эмоцыі фарміруюцца і рэгулююцца соцыумам, патрэбамі асобы і проста канкрэтнымі сітуацыямі. Таму і ў паэзіі Максіма Танка ствараецца новая канцэпцыя чалавечай асобы ў яе абмежаваннях і патэнцыяле.

Як заўважыў Максім Танк - дарма пра песню пьтачиа ў глухога $(3,36)$, дыялог можа адбыцца толькі на адным напружанні думак, агульным узрушэнні душэўных станаў. Песня дасягае адрасата пры сваёй запатрабаванасці, сэнс яе стане зразумелым пры аднолькавым валоданні аўтарам і чытачом знакамі культуры, эмоцыя тэксту чытачом будзе ўспрынята толькі пры злучэнні у адно цэлае гісторыка-літаратурнага і асабістага вопыту. «Другі» ўваходзіць у прастору мастацкага асэнсавання і рэагавання ӱ творчасці Максіма Танка не як «чужы», адрасаванасць, скіраванасць на адрасата - канстытутыўная асаблівасць выказвання, улічваючы і задуму і экспрэсію твора. Пад уздзеяннем рэакцыі «Другога» на выказаныя думкі, на выражаныя пачуцці і перажыванні адбываецца і фарміраванне эмацылнальнага поля твора. Напрыклад, у вершы «У гадавіну знішчэння Хірасімы» Максім Танк гаворыць пра трагедыю далёкай краіны быццам пра гора, якое кранула яго асабіста:

\footnotetext{
Яны прыходзяць да мяне

I песні ад мяне чакаюць.

I песні не пра боль, тугу,

А каб пра шчасце гаварыла...

А я праз слёзы не магу

Пачаць яе над іх магілай $(3,37)$.
}

Эмацыянальнае поле верша складаюць раскіданыя па творы сугестыўныя знакі «болю», «тугі», «шчасця», «слёз», «магілы». Гэта уззнаўляльныя значэнні канструктаў, на асацыятыўным прачытанні сэнсай якіх і будуецца перажыванне. Увогуле, Максім Танк вельмі часта карыстаецца асацыятыўным спалучэннем дадатковых сэнсавых і інтанацыйных адценняў для перадачы эмацыянальна-пачуццёвага зместу твора. Трагедыя Хірасімы для Танка - гэта не столькі рэканструкцыя жудасных падзей мінулага, сколькі горкі напамін аб сэнсе 
жыцця ўсім жывым. Сапраўды, $O$, як забыйліва mbl, / Памяць $i$ necня жывьх! $(3,43)$, а вось для Для мірнай песні прастор шырокі $(3,61)$.

(...) Кожная эпоха - няспынны дылялог паміж тылм, што было, ёсць $i$ тьлм, што нараджаециа, - заўважае $\ddot{y}$ дзённіках Максім Танк. Тое ж можна сказаць пра яго творчасць: паэт увесь час звяртаецца да песні як да дыягназіста, які вызначае адпаведнасць яго мастацкіх намаганняў пастаўленай мэце - ствараць патрэбную людзям паэзію. Таму часта сустрэнем у вершах рэфлексіі адносна мінулых поспехаў і паражэнняў на ніве служэння мастацтву, убачым звароты да песні як інварыянту ўсіх рэалізаваных праектаў у паэзіі і г. д. Максіму Танку важна атрымаць эмацыянальны водгук на напісаны тэкст, «Другі» з'яўляецца на стадыі інтэрыарызацыі вынікаў працы.

Я сэрцам пісаў сваю кожную песню.

А покуль пайшла яна ў свет вандраваць,

Чытаў я таварышам, соснам і далям,

Калоссям жытнёвым і Нарачы хвалям -

Каму я з маленства прывык давяраць.

Няважна, што скажа глушэи-рэчэнзент $(3,120)$

Не будзем аспрэчваць прызнанне Максіма Танка, што яму не важна ацэнка глушиа-рэџэнзента, аднак рэакцыя на твор, хай сабе «Другога» як персаніфікаванага суб'екта, стварала і яго ўласны эмацыянальны вопыт мастака, які праецыраваў яго будучыя творы. Кодэкс выражэння эмоцый у паэзіі Максіма Танка заключаецца у пераканаўчасці, пра што ён разважаў у дзённіках: Жыциё $i$ мастачтва. Апошняе часта бывае больш пераканаўчьм, як жыциё. Дзесьиі чытаў, што актор, які, страчіўшы блізкага яму чалавека, плакаў на сцэне сапрайднымі слязамі $і$ перажываў сапрайднае гора, не ўзрушыу так гледачоў, як тады, калі іграў, імітаваў свае пачуциі $(10,418)$. А пераканаўчасць набываецца з уласным вопытам, фарміруецца на аўтэнтычнасці жыццёвых назіранняў, бо нават апісваючы працу доменнай печы, паэт панаракаў, што меў з ёй мімалётную сустрэчу, а таму: Напэўна, была б мая песня званчэйшай / На тоны рудь залатой багачейшай $(3,125)$.

Гэты нябачны «Другі», прысутнасць якога абавязкова для паэта і які, як рэзанатар, не толькі рэагуе на слова, але і ўзмацняе сілу яго гучання, уступае з аўтарам у нябачны дыялог, дзякуючы чаму аўтар атрымлівае магчымасць літаратурнага апраўдання/пацвярджэння і эстэтызацыі свайго эмацыянальнага вопыту: - Я не памылілася, скажа Радзіма, - / Калісьиі даверыутшы песню яму $(3,121)$. П. К. Ано- 
хін высунуй палажэнне, у адпаведнасці з якім адмоўныя эмацыянальныя станы мабілізуць арганізм на задавальненне патрэб, а станоўчыя эмоцыі з'яўляюцца канечным фактарам, які гэтае самаадчуванне замацоўвае. Відаць, гта справядліва і ў дачыненні да паэтай.

Толькі я хацеў бы скласці песню,

На якой бы ў маім райкоме

Напісалі дарагія словы:

«Прачытай і перадай другому!»

Прачытай і перадай другому! (3, 201).

Прачьтай $і$ перадай другому! - як рэканфігурацыя постмадэрнісцкага «Другога» ў дыскурсе рэалістычнай паэзіі сацыялістычнага грамадства з райкомамі, гаркомамі і іншымі важнымі для асобы партыйнымі ўстановамі. Як чалавек свайго часу, у 1950-60-ыя гады Максім Танк гаварыў мовай і вобразамі савецкай эпохі. Эмацыянальнае поле $\breve{y}$ падобных вершах звужаецца да канстатацыі адданасці краіне, партыі, заваёвам камунізма. У іх выражаецца своеасаблівая гісторыка-палітычная інтэрпрэтацыя знешняга боку жыцця паэта, які свята верыў у «правое дело» сацыялізма і чакаў наступлення эры камунізма. У апошнія гады жыцця, з вышыні розных перажытых падзей са зменамі палітычных рэжымаў, Максім Танк пісаў: Зарана яны паставілі крыж над саиьялізмам, бо ён няўмольна некалі прыйдзе, ачьсційшыся ад усіх сваіх першародных грахоў $і$ скажэнняў, культаў. Бо нават усе нам вядомьия рэлігіі мелі не толькі слаўныя перылды ў сваёй гісторыі. Яшчэ $і$ сёння розныя вызнаўцы Хрыста, Магамета стагоддзямі вядуць братазабойчьля войны. Адна з найвялікшых небяспек, каб здраднічкай $і$ партачкай перабудовай не адкінулі нас на дзесяткі год назад. Баюся, иі гэта адставанне ўдасца калі надрабіџь. Нездарма лідэры капіталізму стараліся з намі расправічща» $(10,697)$. Было б няправільна асуджаць чалавека за яго веру, якая падтрымлівалася і «песняй»-паэзіяй. Максім Танк ніколі не быў аўтаномным суб'ектам, як Д. Сахараў ці А. Салжаніцын, ён заўсёды лічыў сябе неад'емнай часткай радзімы і гэта пазіцыянаваў у якасці грамадскай пазіцыі. Прычым яго актыўнае грамадскае жыццё, займаемыя шматлікія высокія пасты гэту пазіцыю сцвярджалі. I творчае жыццё паэта - своеасаблівая храналогія гісторыі $\mathrm{XX}$ стагоддзя.

У канцэпце песня, такім чынам, знаходзіць адлюстраванне эмацыянальны вопыт паэта: Чую, іржавыя ныюиьасколкі - / $\check{\bar{y}}$ песні маёи $(3,219)$; яна (кальиска - С.К.) і ў песні ёсць маёй, / Хоць з польмя пажарай (Калыска) (5, 22), Бо мой час замнога / ั̆ ліў у яе сло- 
выл / Польля $i$ грому, / Горычы свінцовай (Пакідае сонца) (5, 98); песня прадвызначае эмацыянальны стан аўтара ў цяперашнім і будучым часе: Але гориы яшчэ - / Дзень, без песні пражыты $(3,212)$, адлю-

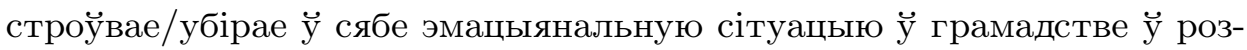
ныя перыяды зломаў/рэвалюцый/пераўтварэнняў, напрыклад: Таму асиерагайчеся, / Бо замест сонца / У нашых песнях - / Небяспечньи строниый (Цяпер асцерагайцеся) $(6,183)$. Максім Танк вызначае вытокі сваёй песні, эмацыянальна-эстэтычнае напаўненне якіх гаворыць пра высокую эмацыянальную культуру яго як аўтара: здабываць з любові - песню (т. 5, 75); I толькі песня / Як алімпійская паходня, / Загараеича ад сонца - / Ад сониа ў сэриы (Песня) (т. 6, 154); Хай перабродзіџь / Хмель жыция $i$ стане ў сэрщь песняй, / Што пачне усе абручь зрыьачь. (Вінароб трымае доўга ў бочцы) $(5,250)$; песняй правярае маральныя імператывы асобаснага самараскрыцця: Kaб $i$ ix мець за сведак / Праўдзівасиі песні маёй $(6,42)$.

Увогуле, у апошнія гады жыцця Максіма Танка вельмі турбавалі пытанні мастацкай этыкі і эстэтыкі, аксіялагічныя і анталагічныя праблемы быцця, якія у многім рэканструявалі яго мастацкія прыёмы і падыходы да творчасці. У апошніх зборніках канцэпт песня трансфармуецца са сродка адлюстравання у сродак самапазнання, самакрытыкі. Як заўважыў Максім Танк у дзённіках: Самы небяспечны перыяд у жыциі мастака - перыяд задавальнення сабой $(10,368) ;$ А да ўсяго нат пры самай большай удачы - заўсёды трэба быџь самакрытычныл, бо адсутнасиь самакрытычнасиі вядзе да застою і небяспечнага графаманства $(10,423)$. Філасофія жыцця, экзістэнцыяльныя праблемы ўваходзяць у паэтычныя роздумы аўтара ў якасці шкалы ў самаідэнтыфікацыйных працэсах. Як ні парадаксальна, і гэта адлюстравана у канцэптуальным раскрыцці вобраза песні, да апошніх дзён паэта турбавалі пытанні, чаго варты яго песні, ці патрэбны яны будуць краіне, людзям: I песні мае, калі варты таго, / Зной людзям калоссямі верне (Нічым не пацешу нашчадкаў сваіх) $(5,39)$. Прысутнасць зваротнай сувязі ў звязцы «аўтар-тэкст-чытач» - гэта тое трыадзінства, дзеля чаго жыў Максім Танк у паэзіі: I песню сваю / Правяраю па рэxy / Y nолі, у лесе, / 亡̆ народзе... (Магчыма) (6, 327). У яго быў свой узровень мастакоўскіх прэтэнзій, так званая мастацкая норма ў бінарнай апазіцыі «верш - не-верш», уласная «дазіметрычная каштоўнасная шкала», па якіх правяралася «якасць» напісанага. У розных варыяцыях на працягу ўсіх гадой творчасці агучваецца тэза, што галоўная песня так і не напісана: 
Я ж па драбіне песні

3 пекла мінуўшчыны

Ўздымаюся да сваёй мары.

Толькі, калі да яе набліжаюся,

Кожны раз яна

Спуджанай птушкай

Ўзлятае вышэй.

Кажуць: сізіфава праца.

Але ніхто мяне не змусіць

Яе спыніць.

Хтось падстаўляе драбіну $(5,54)$

Механізмы і тэхналогіі стварэння тэксту турбуюць аўтара не ў той ступені (хаця ӱ дзённіках паэта знойдзем шмат выказванняў, звязаных з праблемамі структуры верша), як выкананне місіі паэта, таму ў канцэпце песня знаходзіць выяўленне канструяванне сябе самога як паэта $\ddot{y}$ формах разважання над сутнасцю мастацтва. Эстэтызацыя галоўнай эмоцыі $A$ не знойдзе (песня - C. K.) - хай пакліча. / Я $i$ з-пад кургана ўстану (Калі трэба была песня) $(5,11)$ вылілася ў форму пафаснай прысягі, якая адлюстройвала экспрэсію заўсёды гатовай да творчасці асобы, нават у іншым вымярэнні быцця. Місія быць паэтам неаднойчы прымушала задумацца і аб месіянскім уздзеянні слова на людзей:

Каб стварыў такую песню,

Што няўцешлівых пацешыць,

Што сляпым заззяе зоркай,

Што глухім іх голас верне,

Што у сухмень расой напоіць,

Што у мароз акрые світкай,

Што ў галодны час накорміць,

А параненым - залечыць

Незагоеныя раны, -

Найшчасліўшы быў бы ў свеце

I спакойна ў час апошні

Я закрыў бы свае вочы.

Каб стварыў такую песню $(5,52)$

У названым вершы не называецца імя Iісуса, аднак у марах паэта бачыцца эсхаталагічны сэнс - стаць выратавальнікам душ, лекарам цел, як гэта рабіў Iісус. Ачышчэнне ад скверны праз слова - эзатэрычнае жаданне, у якім перакрыжаваліся чалавечыя і боскія сэнсы. У святых пісаннях сказана, што ахвяра Iісуса - ёсць пажытак, не- 
абходны ўсім для вечнага жыцця. Герой Максіма Танка таксама закрые свае вочь - стане ахвярай пасля таго, калі слова яго набудзе прарочую моц. Калі звярнуцца да статыстычных падлікаў у паэтычных творах, то слова «Хрыстос» Максім Танк ужыў два разы, слова «іiсус» - ні разу і «Бог» - 25 разоў (падлік вёўся па 1-6 тамах паэзіі Збору творай Максіма Танка у 13 тамах). Прычым у колькасным эквіваленце пераважае ўжыванне названых слоў у апошнім, 6-ым томе, у які ўключана паэзія з 1983 па 1995 гады. Часцей за ўсё выкарыстанне лексемы «Бог» набывае эмацыянальную афарбоўку, таму што ўваходзіць у склад фразеалагічных зваротаў, кшалту - Бог з ім, слава Богу і г.д. Аднак у 1990-ыя гады паэт усё часцей звяртаецца да вобраза Бога, але гэта асобная тэма для даследавання.

Ці былі у у аўтара эмацыянальныя кантроль і ўпраўленне тактыкай і стратэгіямі пісьма? У давераснёўскі перыяд - безумоўна так, да сённяшняга дня многія тэксты засталіся зашыфраванымі з-за канспірацый паэта. I ў ваенны перыяд таксама, таму што пасля абвінавачвання бацькой, залічаных да кулакоў, Максім Танк знаходзіўся пад пільнай увагай пэўных структур улады. У пасляваенны перыяд Максім Танк замацоўваў статус беларускага, а не толькі заходнебеларускага паэта, таму яму нельга было «ачарніць» сябе непатрэбшчынай у ідэйна-тэматычным выбары. А пасля таго, як стаў галоўным рэдактарам часопіса «Полымя», пераўтварыўся ў публічную асобу, адказную за кожнае выказанае слова. Ці адбываецца поўнае супадзенне знешняга і ўнутранага «я» асобы Максіма Танка? Ці не канфліктуюць паміж сабой гэтыя дзве розныя іпастасі аўтара ў працэсе стварэння мастацкага твора? Раскрыццё гэтых праблем, звязаных з псіхалогіяй творчасці, у многім дапамагло б нам разабрацца з акрэсліваннем эмацыянальнага інтэлекту паэта Максіма Танка, аднак гэта больш прадмет даследавання псіхалогіi, чым літаратуразнаўства. Па ўспамінах людзей, якія ведалі асабіста паэта, ён быў чалавекам камунікабельным, вясёлым, з выдатным пачуццём гумару, у яго заўсёды «пад рукой» знаходзілася цікавая гісторыя, часта з іранічным развіццём сюжэта. Ён мог гадзінамі трымаць увагу суразмоўцаў ці аўдыторыі, перад якой выступаў. Як гаварыў пра сябе Максім Танк, прадказай мне лёс неспадзяваньи, / Лёс ваганта - песняра, бадзіні / Па зямных $і$ незямных краінах (На рынку) (6, 274), і лёс паэта-«валацугі», які палову жыцця у прамым сэнсе слова правёў у паездках па розных краінах свету, у вандройцы (Несціхана шуміце) $(6,102)$, ён прыняў і як дар нябёсаў, і як іх пракляцце. 
Вы думаеце, гэта - шчасце,

Калі ад дотыку твайго

Ператвараецца ўсё у песню:

Зямля, трава, вада, агонь,

І хлеб, і соль, і боль, і радасць,

I кожны міг, і кожны час...

Як позна зразумеў, дзівак, я

Тваю трагедыю, Мідас!

Bbl думаече, гэта - шчасие $(3,246)$

Максім Танк не займаецца гульнёй у маскі, мы не сустрэнем у яго парада эмацыянальных суб'ектаў - аўтарскіх копій, мы не заблытаемся ў вызначэнні сапраўднага «я» і таго, які знаходзіцца на падмостках тэатру, яго цэльнае аўтарскае «я» мае храналогію пасталення і мастацкі вопыт, але ядро ці стрыжань гэтай ментальнай фігуры - Аўтар - вызначае сумленнасць перад чытатом і самім сабой. Амбівалентнасць вобраза песні $\breve{y}$ вершы «***Вы думаеце, гэта - шчасце...» выклікана ўзвядзеннем песні $\ddot{y}$ культ, у якой перакрыжаваліся розныя сілы ўздзеяння на асобу - розуму, творчай фантазіі, эмоцыі, настрою, перажывання і г. д. Як фокуснік, аўтар жангліруе вобразамі і у гэтым бачыць трагедыю. У эмацыянальным фокусе спайваецца росквіт паэтычнага майстэрства і крызіс ад усведамлення незадавальнення зроб-

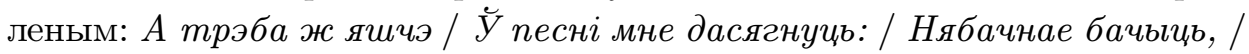
Нячутнае чущь (Як доўга вучыўся) (5, 70). Асоба аўтара ў апошніх зборніках паўстае у раздвоенай ідэнтычнасці: шчаслівага ўладальніка паэтычнага дару і рэфлексуючага ўнутранага крытыка. Гэтыя паралельныя стратэгіі ў станаўленні творчай індывідуальнасці Максіма Танка адлюстройвалі адзін бок мастацка-культурнай ідэнтыфікацыі аўтара як чалавека адказнага за сваё ролевае выкананне ў беларускай літаратуры і сваім чалавечым лёсе на роднай зямлі. Яго мастацкі эмацыянальны стыль раскрываецца праз кодэкс эмоцый, сфармуляваных у кананічных для эпохі XX стагоддзя і нават апярэджваючых свой час творах. 
S T R E S Z C Z E N I E

\title{
KONCEPT EMOCJONALNY: \\ TEORIA I PRAKTYKA ZASTOSOWANIA W POEZJI MAKSYMA TANKA
}

W artykule przedstawiono teoretyczne znaczenie terminu „koncepcja emocji” oraz jej zastosowanie w poezji Maksyma Tanka. Szczególną uwagę zwrócono na ścisły związek pomiędzy koncepcją emocji i emocjonalnym intelektem oraz na specyficzne dla poety sposoby opisywania jedności człowiek-świat. Emocjonalny styl Maksyma Tanka rozwija się poprzez kodeks emocjonalny zawarty w jego utworach, które stanowią kanoniczną wartość literatury XX wieku.

Słowa kluczowe: przestrzeń emocjonalna, wiersze, pole emocjonalne, twórczość Maksyma Tanka.

\author{
S U M M A R Y
}

THE EMOTIONAL CONCEPT:

\section{ITS THEORY AND PRACTICE IN MAKSYM TANK'S POETRY}

In the article theoretical meaning of "emotional concept" in Maksym Tank's poetry is discussed. Emotional concept is connected with emotional intellect. Special attention is focused on the author's individual ways of showing man-world unity. Maksym Tank's emotional style develops through emotional code formed in his canonical literary works.

Key words: emotional concept, emotional space, emotional field, Maksym Tank's creative work. 